\title{
Nutritional Value and Potential Chemical Food Safety Hazards of Selected Traditional and Conventional Pork Hams from Poland
}

\author{
Michał Halagarda, Władysław Kędzior, and Ewa Pyrzyńska \\ Department of Food Commodity Science, Cracow University of Economics, Ul. Sienkiewicza 5, 30-033 Kraków, Poland \\ Correspondence should be addressed to Michał Halagarda; michal.halagarda@uek.krakow.pl
}

Received 13 June 2017; Accepted 30 July 2017; Published 20 September 2017

Academic Editor: Jesús Lozano

Copyright (c) 2017 Michał Halagarda et al. This is an open access article distributed under the Creative Commons Attribution License, which permits unrestricted use, distribution, and reproduction in any medium, provided the original work is properly cited.

Consumers no longer look for food characterized only by health safety and proper nutritional value. As a result, an increased interest in traditional and regional food can be observed. The aim of this paper is to analyze the results of a comparative analysis of three types of hams: traditional products registered on the List of Traditional Products of the Polish Ministry of Agriculture and Rural Development, then products whose names, retail prices, appearance, and manufacturer's description suggest traditional methods of production, and finally conventional hams. The results show that traditional hams are characterized by the highest nutritional value among the analyzed groups of products. They have the lowest water and a high protein content. In addition, traditional hams are distinguished by a low concentration of sodium chloride and no addition of phosphates. The residues of nitrites and nitrates indicate their moderate use in manufacturing processes.

\section{Introduction}

Modern-day consumers no longer look for food characterized only by its health safety and proper nutritional value. They expect products that stand out thanks to their sensory properties, high quality, and natural composition. As a result, an increased interest in traditional and regional food can be observed. Such products, due to the use of specific methods of growing plants, natural methods of breeding animals, and mainly good traditional processing technologies, are characterized by a specific appearance, smell, and taste [1-3].

The European Union has been supporting multidirectional rural development for years. Conditions for manufacturers, enabling them to compete on the world markets, have been created. For this reason, instruments to help protect those manufacturers who ensure the quality and unique organoleptic characteristics of their products have also been developed. The Regulation (EU) No 1151/2012 of the European Parliament and of the Council of 21 November 2012 on quality schemes for agricultural products and foodstuffs, which introduces the possibility of product registration and grants them the status of Protected Designation of Origin,
Protected Geographical Indication or Guaranteed Traditional Specialties is in force. Products approved by the European Commission may use the appropriate logo. As a result, they become easily identifiable by consumers. This in turn contributes to the growth of their reputation and may become an important element in stimulating their purchases.

Polish meat industry has a long tradition in the production of smoked meats with exceptional taste. The animals are reared using traditional feeds such as potatoes and green fodder, which positively affect the sensory qualities and other characteristics of meat quality. In addition, proper selection of raw materials and spices and the use of unique production methods for many years have given the indigenous products a unique appearance, taste, and aroma [4]. Processed meat products are very willingly bought by consumers. It is estimated that the average household buys from 250 to 500 grams of processed meat products a week, and as many as $50 \%$ of consumers eat such products at least five times a week [5].

Poland is a country with very varied terrain and climate, and thus it has ample possibilities for crops cultivation and animal breeding. These factors, together with 
the temperament and habits of the folk, have led to the development of a number of unique products specific to certain areas. Unfortunately, in the list of products registered by the European Commission, there are only four Polish meat products. Three of them are Traditional Speciality Guaranteed: jałowcowa sausage, myśliwska sausage, and kabanosy. Lisiecka sausage as the fourth product has a Protected Geographical Indication. However, the List of Traditional Products made from meat is very long and many of them have a chance to be registered at the European Union level as regional products or Traditional Specialty Guaranteed [13].

In Poland, however, there is a possibility of registering a product on the List of Traditional Products of the Polish Ministry of Agriculture and Rural Development. The aim is to identify traditional products available on the domestic market, characterized by a unique quality achieved by the use of old recipes and traditional methods of production and processing. It can also be treated as the first step in the preparation of manufacturers to register their products on the EU level.

Only products which are part of the cultural heritage of the region and have at least a 25 -year tradition of manufacturing, which must be thoroughly documented by presenting old labels, photographs, recipes, and so forth, can enter the List of Traditional Products. Nevertheless, the methods of production and the characteristics of products do not need to be related to the region of their production [14].

In the production process of traditional meat products, only natural ingredients (i.e., meat, salt, natural spices, e.g., garlic, onion, black or green pepper, cumin, bay leaf, etc.) are used. It is not allowed to use any artificial additives, improvers, fillers, or preservatives, with an exception of a mixture of salt and nitrite. In order to extend the shelf life of the products, they are subjected to the processes of drying or smoking. Smoked meats are produced in smokehouses with the use of natural carefully selected wood, without any addition of smoke flavorings.

Unfortunately, alongside traditional meat products, a wide range of high-performance products at a lower price is available on the market. Such products are, however, manufactured using the technology that requires the use of many additives. Meat is injected with brine and expensive raw materials are replaced by cheaper substitutes [5].

The aim of this study is to investigate the possible differences in the nutritional value and to determine potential chemical hazards in three groups of meat products: the ones registered on the List of Traditional Products of the Polish Ministry of Agriculture and Rural Development; products whose appearance, name, price, and the description of the manufacturer indicate their traditional character, but which have not been registered on the abovementioned list, and conventional (mass) products.

\section{Material and Methods}

The research material consisted of 9 varieties of smoked pork hams available on the Polish market, which were put into three groups. Group I comprised 2 product varieties that were on the List of Traditional Products of the Polish Ministry of
Agriculture and Rural Development. Group II was formed of the samples representing products whose names, retail prices, appearance, and manufacturer's description suggested traditional methods of production (3 varieties) and group III was formed of conventional products with low retail prices (4 varieties). Six hams of each variety were purchased in different marketplaces in manufacturers' stores, delicatessens, and supermarkets.

The research program was developed on the basis of literature data and the Polish Standard PN-A-82007:1996/A1:1998.

The nutritional value of hams was specified based on selected indicators: protein, water, fat, sodium chloride, total ash, Feder's number, $\mathrm{Ca}, \mathrm{Fe}, \mathrm{Mg}, \mathrm{K}, \mathrm{Zn}, \mathrm{Cr}$, and $\mathrm{Cu}$.

The chemical food safety of hams was determined based on selected indicators: nitrates and nitrites, total and added phosphorus, $\mathrm{Cd}$, and $\mathrm{Pb}$.

The selected parameters were determined using the methods indicated in Table 1.

A one-way ANOVA followed by pairwise $t$-test with Bonferroni correction was used to compare the means of the analysis results for the examined categories of hams. A value of 0.05 was required for statistical significance.

Profile charts were used in order to illustrate the differences between the analyzed groups of products. They show the determined values in the form of rectangles. The larger the rectangles are, the more the actual value deviates from the average total value of the specific parameter calculated for all products tested. The red rectangle represents variations in plus and the blue one in minus.

\section{Results and Discussion}

3.1. Nutritional Value. Meat and meat products are a source of many important nutrients and therefore should be included in a well-balanced diet $[15,16]$. The nutritional value of meat products is determined by the composition of raw materials and depends primarily on the ratio of proteins, fats, and water. The correct ratio of these components is also one of the main factors determining the attractiveness of the product for consumers. The content of collagen and elastin (connective tissue proteins) and the possible addition of plant-based proteins are also important. Hams usually have the highest protein content among all of the meat products $[17,18]$. The literature highlights a wide variation between the nutritional values of meat products manufactured with the use of industrial methods and those that have been produced without additives.

The parameters affecting nutritional value of hams analyzed in this study are shown in Table 2. Profile chart (Figure 1) illustrates the differences between three analyzed groups of hams in terms of the nutritional value parameters examined.

3.1.1. Protein. The analyzed hams contained on average $20.7 \%$ proteins. The highest concentrations of this nutrient were determined in the products registered on the List of Traditional Products of the Ministry of Agriculture and Rural Development (group I), an average of $25.5 \%$. Unregistered traditional products (group II) contained on average $22.8 \%$ 
TABLE 1: Methods used to determine selected parameters.

\begin{tabular}{|c|c|}
\hline Parameter & Research method \\
\hline Protein & $\begin{array}{l}\text { Kjeldahl's method with the use of Büchi wet digester B-426 coupled with scrubber B-414 and distillation unit } \\
\text { K-314 [6] }\end{array}$ \\
\hline Water & Oven-drying method [7] \\
\hline Fat & Soxhlet method with the use of Büchi extraction system B-811 [8] \\
\hline Sodium chloride & Mohr's method [9] \\
\hline Total ash & Incineration in $550 \pm 25^{\circ} \mathrm{C}$ with prior carbonization with the use of Nabertherm P-300 furnace [10] \\
\hline Nitrates and nitrites & $\begin{array}{l}\text { Enzymatic reduction of nitrates to nitrites and with the use of Thermo Scientific Aquamate Plus UV-Vis } \\
\text { Spectrophotometer [11] }\end{array}$ \\
\hline $\begin{array}{l}\text { Total phosphorus } \\
\text { expressed as } \mathrm{P}_{2} \mathrm{O}_{5}\end{array}$ & With the use of Thermo Scientific Aquamate Plus UV-Vis Spectrophotometer [12] \\
\hline $\begin{array}{l}\text { Added phosphorus } \\
\text { expressed as } \mathrm{P}_{2} \mathrm{O}_{5}\end{array}$ & $\begin{array}{l}\text { Calculated according to the equation } \\
\qquad \mathrm{AD}=2.29 \times 10\left(\frac{\mathrm{TP}}{2.29}-0.01 \times P\right) \\
\text { (where } \mathrm{AD} \text { is the added phosphorus, TP is the total phosphorus, and } P \text { is protein) }\end{array}$ \\
\hline $\begin{array}{l}\text { Water/protein ratios } \\
\text { (Feder's numbers) }\end{array}$ & $\begin{array}{l}\text { Calculated according to the equation } \\
\qquad \mathrm{FN}=\frac{W}{P} \\
\text { (where FN is Feder's number, } W \text { is water, and } P \text { is protein) }\end{array}$ \\
\hline $\mathrm{Ca}, \mathrm{Fe}, \mathrm{Mg}, \mathrm{K}, \mathrm{Zn}$ & $\begin{array}{l}\text { Atomization in the flame with the deuterium lamp background correction Samples of } 0.45 \text { to } 0.55 \mathrm{~g} \text { were } \\
\text { mineralized in a mixture of } 65 \% \mathrm{HNO}_{3} \text { and } 30 \% \mathrm{H}_{2} \mathrm{O}_{2}(7: 1 \mathrm{~V} / \mathrm{V}) \text { at } 200^{\circ} \mathrm{C} \text { in a Milestone Start } \mathrm{D} \text { microwave. } \\
\text { The obtained solutions were quantitatively transferred to volumetric flasks and diluted to } 50 \mathrm{ml} \text {. The solutions } \\
\text { were analyzed by atomic absorption with the use of Thermo Scientific iCE } 3500 \text { apparatus }\end{array}$ \\
\hline $\mathrm{Cd}, \mathrm{Cr}, \mathrm{Cu}, \mathrm{Pb}$ & $\begin{array}{l}\text { Atomization in a graphite tube, with the background correction based on the Zeeman effect. Samples of } 0.45 \text { to } \\
0.55 \mathrm{~g} \text { were mineralized in a mixture of } 65 \% \mathrm{HNO}_{3} \text { and } 30 \% \mathrm{H}_{2} \mathrm{O}_{2}(7: 1 \mathrm{~V} / \mathrm{V}) \text { at } 200^{\circ} \mathrm{C} \text { in a Milestone Start } \mathrm{D} \\
\text { microwave. The obtained solutions were quantitatively transferred to volumetric flasks and diluted to } 50 \mathrm{ml} \text {. The } \\
\text { solutions were analyzed by atomic absorption with the use of Thermo Scientific iCE } 3500 \text { apparatus }\end{array}$ \\
\hline
\end{tabular}

TABLE 2: Selected parameters used to verify the nutritional value of sample hams.

\begin{tabular}{|c|c|c|c|c|c|}
\hline \multirow{2}{*}{ Parameter } & \multicolumn{5}{|c|}{ Group of products } \\
\hline & Total & Group I $(n=12)$ & Group II $(n=18)$ & Group III $(n=24)$ & $P$ \\
\hline Water [\%] & $68.7(5.44)$ & $63.4(4.02)^{\mathrm{ab}}$ & $66.7(4.10)^{\mathrm{ac}}$ & $73.1(3.20)^{\mathrm{bc}}$ & $<0.001$ \\
\hline Protein [\%] & $20.7(4.86)$ & $25.5(2.64)^{\mathrm{ab}}$ & $22.8(4.22)^{\mathrm{ac}}$ & $16.6(2.15)^{b c}$ & $<0.001$ \\
\hline Fat [\%] & $6.40(4.88)$ & $8.56(5.53)$ & $5.71(5.60)$ & $5.81(3.68)$ & 0.222 \\
\hline Total ash [\%] & $3.16(0.58)$ & $2.44(0.40)^{\mathrm{ab}}$ & $3.26(0.51)^{\mathrm{a}}$ & $3.45(0.38)^{\mathrm{b}}$ & $<0.001$ \\
\hline Sodium chloride [\%] & $2.43(0.40)$ & $2.09(0.41)^{\mathrm{ab}}$ & $2.50(0.40)^{\mathrm{a}}$ & $2.56(0.28)^{\mathrm{b}}$ & 0.001 \\
\hline Water/protein ratio & $3.53(0.97)$ & $2.51(0.19)^{\mathrm{ab}}$ & $3.01(0.52)^{\mathrm{ac}}$ & $4.47(0.54)^{\mathrm{bc}}$ & $<0.001$ \\
\hline $\mathrm{Fe}[\mathrm{mg} / \mathrm{kg}]$ & $5.15(2.35)$ & $6.16(2.60)$ & $4.95(2.49)$ & $4.80(2.17)$ & 0.504 \\
\hline $\mathrm{Zn}[\mathrm{mg} / \mathrm{kg}]$ & $21.6(6.07)$ & $27.3(6.21)^{\mathrm{a}}$ & $22.7(5.22)^{b}$ & $18.0(4.10)^{\mathrm{ab}}$ & 0.003 \\
\hline $\mathrm{Mg}[\mathrm{mg} / \mathrm{kg}]$ & $184(35.1)$ & $174(28.5)^{\mathrm{a}}$ & $207(46.1)^{\mathrm{ab}}$ & $171(18.2)^{\mathrm{b}}$ & 0.045 \\
\hline $\mathrm{K}[\mathrm{mg} / \mathrm{kg}]$ & $2936(612)$ & $2475(310)^{\mathrm{a}}$ & $3493(567)^{\mathrm{ab}}$ & $2749(448)^{\mathrm{b}}$ & 0.001 \\
\hline $\mathrm{Ca}[\mathrm{mg} / \mathrm{kg}]$ & $133(55.0)$ & $100(20.6)^{\mathrm{a}}$ & $87.3(12.8)^{\mathrm{b}}$ & $182(43.5)^{\mathrm{ab}}$ & $<0.001$ \\
\hline $\mathrm{Cr}[\mu \mathrm{g} / \mathrm{kg}]$ & $55.5(62.3)$ & $55.0(43.8)$ & $50.6(72.5)$ & $59.5(66.6)$ & 0.953 \\
\hline $\mathrm{Cu}[\mu \mathrm{g} / \mathrm{kg}]$ & $1305(846)$ & $1602(643)$ & 1451 (1173) & 1047 (605) & 0.360 \\
\hline
\end{tabular}

Group I: products on the List of Traditional Products of the Polish Ministry of Agriculture and Rural Development. Group II: products whose names, retail prices, appearance, and manufacturer's description suggest traditional methods of production. Group III: conventional products. Letter symbols were used to mark statistically significant differences.

proteins. The smallest amounts of proteins were noted in conventional products, an average of $16.6 \%$. These differences were statistically significant.

It should be noted, however, that one of the unregistered traditional products contained in its composition liquid protein hydrolysate on the basis of maize and rapeseed, whereas conventional hams contain either milk protein, pork collagen, or soy protein, which resulted in an increase of the concentration of protein in these products.

The protein content similar to the group I products was found in the long maturing ham of the premium segment tested by Florek et al. [5] (25.8\%). Yet, the imported hams 


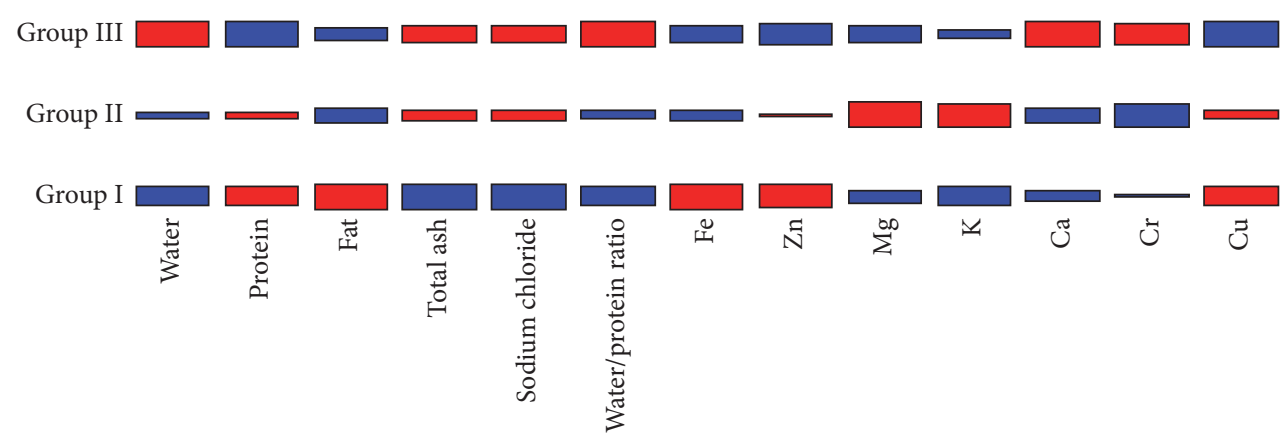

FIgURE 1: Profile chart - nutritional value parameters.

examined by them contained on average $23.38 \%$ of that nutrient. Maturing hams are characterized by a higher protein content, an average of 30\% [19]. The findings of Lucarini et al. [20] show that the long maturing hams (Modena, Nazionale, Parma, and San Daniele) contained on average $26.2 \%$ protein. Also, Marušić et al. [21] showed that the Istrian hams contained on average $32.4 \%$ protein in 2010 and $43.1 \%$ in 2012. Similar content of protein in conventional products analyzed in this study was determined by Szmańko et al. [22] for cooked hams, from $15.58 \%$ to $17.55 \%$, and smoked hams examined by Florek et al. [23], an average of $15.9 \%$. Italian cooked hams investigated by Lucarini et al. [20] contained on average $17.1 \%$ protein. Larger amounts of protein were detected by Szymański et al. [24] in smoked hams. The average content of this nutrient in years 2000-2008 ranged from 16.8 to $19.4 \%$. Grabowska et al. [25] obtained lower average protein content for traditional smoked meat products (21.26\%) and local products (20.06\%) than those determined in this study for traditional products registered on the List of Traditional Products of the Polish Ministry of Agriculture and Rural Development (25.5\%) and traditional unregistered products $(22.8 \%)$. In their research, however, conventional products contained more protein $(19.7 \%)$ in comparison to the content of this nutrient in group III products (16.6\%).

3.1.2. Fat. The average fat content of the analyzed hams was $6.4 \%$. The products in group I had the highest concentration of fat $(8.56 \%)$. The average fat content in group II was $5.71 \%$ and in group III $5.81 \%$. Due to the high variability of this parameter for the majority of product varieties, there were no statistically significant differences between the average contents of fat for the three analyzed groups.

Florek et al. [23] noted $2 \%$ of fat in conventional pork ham, which is a similar value to the lowest concentrations obtained in this study. Imported hams investigated by them contained more fat, an average of $11.13 \%$. The fat content in the cooked hams studied by Szmańko et al. [22] ranged from $3.83 \%$ to $7.21 \%$. Szymański et al. [24] determined an average of $6.4 \%$ to $8.4 \%$ of fat in smoked hams in the years $2006-2008$. Hams studied by Grześkowiak et al. [26] contained on average $3.51 \%$ of fat. Fat content in traditional hams analyzed by Grabowska et al. [25] amounted to $16.25 \%$ on average. This value is significantly higher than that obtained in the present study $(8.56 \%)$. It should be, however, noted that the standard deviation in their study was quite large (14.47). In their research, conventional and local hams were characterized by a lower fat content: $9.29 \%$ and $4.38 \%$, respectively. Lucarini et al. [20] determined the average fat content for Italian cooked hams of $9.6 \%$. The value is similar to the content obtained in the present study for registered traditional products.

Long maturing hams, however, contain large amounts of fat due to a thick layer of fat surrounding the pig muscles. For instance, jamón ibérico contains 19.2\% fat [27], Parma ham $18.4 \%$, and San Daniele ham 23\% [28]. The fat content of ten hams analyzed by Fernández et al. [29] ranged from $17.2 \%$ for Jamo'n Serrano hams to 29.2\% for the Dehesa de Extremadura hams. Hams examined by Lucarini et al. [20], Modena, Nazionale, Parma, and San Daniele, were characterized by an average fat content of $18.4 \%$. There are exceptions, though. For example, Bayonne ham analyzed by Jiménez-Colmenero et al. [30] contained an average of $3.05 \%$ fat. Istrian hams studied by Marušić et al. [31] contained an average of $9.96 \%$ fat. However, the same hams analyzed by Marušić et al. [21] contained $13.5 \%$ fat in 2010 and $17 \%$ fat in 2012.

3.1.3. Water. The water content in meat products is mainly a result of its concentration in meat and fat raw materials. In the technological processes, water loss occurs. It results in the production yield being lower than $100 \%$. In the case of highyield meat products, additives (i.e., phosphates, vegetable or animal proteins, starches, and carrageenan) are used to improve the water binding [17].

The water content differed significantly between the analyzed groups of products. Products registered on the List of Traditional Products of the Polish Ministry of Agriculture and Rural Development contained on average 63.4\% water, unregistered traditional products contained $66.7 \%$, and conventional products contained $73.1 \%$. However, conventional products contained polyphosphates in their composition, which improve water absorption properties of meat.

Szymański et al. [24] obtained the average water content in the range of $68.2 \%$ to $75.6 \%$ for smoked hams analyzed in the years 2000-2008. These values are similar to the ones obtained for conventional hams in this study. Kunachowicz et al. [32] determined the average water content in cooked pork ham at the level of $63.5 \%$ and at the level of $60.8 \%$ in smoked ham. Cooked ham analyzed by Lucarini et al. [20] contained on average $69.7 \%$ water, which is similar to the average obtained in the present study (68.7\%). Long maturing hams, due to the technological process, contain substantially 
less water. Average water content in the Istrian hams analyzed by Marušić et al. [31] was 39.7\% and that analyzed by Marušić et al. [21] was $41 \%$ in 2010 and $37.9 \%$ in 2012, whereas in Italian hams (Modena, Nazionale, Parma, and San Daniele) analyzed by Lucarini et al. [20], the water content stood at $49.2 \%$.

3.1.4. Total Ash. Total ash is an approximation of mineral content in the product. It represents the residue after dry mineralization of organic substances contained in the sample.

A group of traditional hams were characterized by statistically significantly lowest total ash content (average of $2.44 \%$ ). Unregistered traditional products contained more total ash (an average of $3.26 \%$ ). The highest ash content was noted for conventional products (an average of 3.45\%). Differences between groups II and III were not statistically significant. The average for all tested samples was $3.16 \%$. Higher concentrations of total ash determined for conventional products may be associated with the addition of polyphosphates in their production processes.

Grześkowiak et al. [26] noted the average ash content of $3.17 \%$ in four smoked hams. Lucarini et al. [20] in the study of Italian cooked hams received a lower total ash content: $2.7 \%$. Marušić et al. [31], due to the high content of sodium chloride, determined significantly higher concentrations of total ash in Istrian hams, an average of $11.53 \%$. Further research on Istrian hams proved lower concentrations of total ash, $7.2 \%$, in samples tested in 2010 and $6.7 \%$ in samples tested in 2012 [21]. Long maturing Italian hams tested by Lucarini et al. [20] were also characterized by high total ash content: the average amount was $5.8 \mathrm{~g}$ per $100 \mathrm{~g}$ of the product.

3.1.5. Sodium Chloride. There has been a tendency to reduce sodium chloride in meat products. This is partly caused by the use of additives enhancing flavor of products, such as sodium glutamate, as well as the compounds which have a synergistic action with sodium chloride such as phosphates $[24,33]$. Another reason is that too much sodium consumed with food may cause hypertension or high blood pressure [34].

The hams investigated in this study contained an average of $2.43 \%$ of sodium chloride. The highest average concentrations were detected in conventional products $(2.56 \%)$ and unregistered traditional hams (2.5\%). Products registered on the List of Traditional Products of the Polish Ministry of Agriculture and Rural Development contained statistically significantly less salt than other products (2.09\% on average).

Long maturing hams contain significantly more salt. The amount of salt added depends on the size of its particles, amount of fat surrounding the pig's muscle, and the length of drying and desalination processes [31]. Istrian hams examined by Marušić et al. [31] contained on average $9.06 \%$ sodium chloride and those examined by Marušić et al. [21] contained $7.4 \%$ in 2010 and $6.3 \%$ in 2012. Cooked hams analyzed by Szmańko et al. [22] also contained more sodium chloride than the products of all the groups studied, from $3.0 \%$ to $3.59 \%$. Grabowska et al. [25] obtained an average of $2.9 \%$ sodium chloride content in traditional hams. Smoked hams tested by Florek et al. [23] were characterized by an average salt content of $2.7 \%$, a value close to the maximum obtained in these studies. Szymański et al. [24] found that the average content of salt in the smoked hams over the years 2000-2008 decreased from $2.64 \%$ to $2.12 \%$. This is inconsistent with the results of this study. Only products registered as traditional showed similar values to those obtained by Szymański et al. [24] in the last years of their study. On the other hand, the hams analyzed by Grześkowiak et al. [26] had practically identical average sodium chloride content in comparison to the average level observed in all groups of hams of the present study, $2.42 \%$.

3.1.6. Water/Protein Ratio. Calculation of water/protein ratio (called Feder's number) is a parameter allowing determining the quality of meat products. The lower the value of this parameter, the higher the nutritional value of the product [24]. It should be noted, however, that the value of Feder's number changes with the shelf life of the product, because the water content is decreasing. Papadima and Bloukas [35] found that in the case of Greek traditional sausages this coefficient has dropped from 5.29 to 2.59 within 21 days of storage. Feder's number can also be used to determine the addition of water to the product and efficiency of the production process. Nevertheless, any supplementation of the product with the nonanimal protein and/or phosphates may artificially lower the value of this ratio [36].

The average water/protein ratio in the analyzed hams accounted for 3.53. Conventional products were characterized by the highest Feder's number (average of 4.47), followed by the unregistered traditional products (average 3.01). The products registered on the List of Traditional Products of the Polish Ministry of Agriculture and Rural Development had the most preferred water/protein ratio (average of 2.51). The differences between the analyzed groups of hams were statistically significant.

Szymański et al. [24], in the second round of their research (2005-2008), received similar values of Feder's numbers to the average of this study, from 3.79 to 3.51 . They also noted positive downward trend of this ratio in the case of smoked hams. In 2000, the average Feder's number they determined was in fact 4.26.

3.1.7. Mineral Compounds. The human body needs minerals for proper functioning. These compounds are exogenous, and thus they must be ingested with food. Minerals are divided into microelements, also known as trace elements (e.g., iron, copper, zinc, manganese, and molybdenum), and macroelements (e.g., calcium, phosphorus, magnesium, sodium, potassium, and chloride). A subgroup of microelements, for which the body has a very low demand (e.g., nickel, chromium, selenium, tin, vanadium, fluoride, and silicon), can also be distinguished. Minerals play a very important role, including tissue building, providing a waterelectrolyte balance of the body, and being a part of enzymes and hormones [37].

Meat products are good sources of some minerals, especially iron, zinc, copper, and magnesium in well-absorbable form [16]. The concentrations of the following minerals were determined in the ham samples tested: calcium, zinc, iron, 
TABLE 3: The content of selected parameters used to verify the chemical food safety of sample hams.

\begin{tabular}{|c|c|c|c|c|c|}
\hline \multirow{2}{*}{ Parameter } & \multicolumn{5}{|c|}{ Product } \\
\hline & Total & Group I $(n=12)$ & Group II $(n=18)$ & Group III $(n=24)$ & $P$ \\
\hline Total phosphorus $\left[\% \mathrm{P}_{2} \mathrm{O}_{5}\right]$ & $0.55(0.11)$ & $0.41(0.04)^{\mathrm{ab}}$ & $0.53(0.06)^{\mathrm{ac}}$ & $0.64(0.06)^{b c}$ & $<0.001$ \\
\hline Added phosphorus $\left[\% \mathrm{P}_{2} \mathrm{O}_{5}\right]$ & $0.12(0.13)$ & $0.00(0.00)^{\mathrm{ab}}$ & $0.04(0.04)^{\mathrm{ac}}$ & $0.26(0.09)^{\mathrm{bc}}$ & $<0.001$ \\
\hline Nitrites $[\mathrm{mg} / \mathrm{kg}]$ & $20.7(19.3)$ & $13.3(8.41)^{\mathrm{a}}$ & $9.02(6.15)^{b}$ & $33.2(22.7)^{\mathrm{ab}}$ & 0.006 \\
\hline Nitrates $[\mathrm{mg} / \mathrm{kg}]$ & $16.2(11.1)$ & $19.8(12.6)$ & $17.7(11.5)$ & $13.3(10.2)$ & 0.46 \\
\hline Total nitrates and nitrites $[\mathrm{mg} / \mathrm{kg}]$ & $36.9(20.3)$ & $33.2(14.5)$ & $26.7(15.0)$ & $46.5(22.8)$ & 0.07 \\
\hline $\mathrm{Cd}[\mu \mathrm{g} / \mathrm{kg}]$ & $3.92(3.20)$ & $4.61(3.15)$ & $2.74(2.68)$ & $4.46(3.56)$ & 0.415 \\
\hline $\mathrm{Pb}[\mu \mathrm{g} / \mathrm{kg}]$ & $29.9(31.4)$ & $49.4(33.6)$ & $16.2(19.0)$ & $30.5(34.5)$ & 0.132 \\
\hline
\end{tabular}

Group I: products on the List of Traditional Products of the Polish Ministry of Agriculture and Rural Development. Group II: products whose names, retail prices, appearance, and manufacturer's description suggested traditional methods of production. Group III: conventional products. Letter symbols were used to mark statistically significant differences.

magnesium, potassium, cadmium, chromium, copper, and lead.

The average content of iron $(\mathrm{Fe})$ in the analyzed hams was $5.15 \mathrm{mg} / \mathrm{kg}$. The highest concentrations of this element were noted for products of group I, the lowest for conventional products $(6.16 \mathrm{mg} / \mathrm{kg}$ and $4.8 \mathrm{mg} / \mathrm{kg}$, resp.). Differences between the analyzed groups were, however, statistically insignificant.

The results of the study have shown that the average content of zinc $(\mathrm{Zn})$ in hams was $21.6 \mathrm{mg} / \mathrm{kg}$. As in the case of iron, the highest concentrations of zinc were determined in the products registered on the List of Traditional Products of the Polish Ministry of Agriculture and Rural Development (on average $27.3 \mathrm{mg} / \mathrm{kg}$ ) and the lowest in the conventional products $(18 \mathrm{mg} / \mathrm{kg})$. There were statistically significant differences between groups I and III as well as groups II and III.

The average content of magnesium $(\mathrm{Mg})$ in the tested hams accounted for $184 \mathrm{mg} / \mathrm{kg}$. The highest content of this element was found in the products of group II, the lowest in conventional hams. There were statistically significant differences between groups I and II, as well as groups II and III.

The ham samples tested proved to be a relatively good source of potassium $(\mathrm{K})$. The average content of this element was at a level of $2936 \mathrm{mg} / \mathrm{kg}$. The highest concentrations of potassium were found in unregistered traditional products (3493 mg/kg), while the lowest concentrations were found in registered traditional products $(2475 \mathrm{mg} / \mathrm{kg})$. Statistically significant differences were found between groups I and II, as well as groups II and III.

The average calcium ( $\mathrm{Ca}$ ) content in analyzed hams accounted for $133 \mathrm{mg} / \mathrm{kg}$. The highest concentration levels were observed for the products of group III and the lowest for the products of group II (average of $182 \mathrm{mg} / \mathrm{kg}$ and $87.3 \mathrm{mg} / \mathrm{kg}$, resp.). Statistically significant differences were found between groups I and III, as well as groups II and III.

Chromium and copper are ultratrace elements. They might be toxic at elevated concentrations [38]. The average chromium content in the ham samples tested accounted for $55.5 \mu \mathrm{g} / \mathrm{kg}$. The values for each group were similar; $P$ value was close to 1 . The average copper content was $1305 \mu \mathrm{g} / \mathrm{kg}$. The highest concentrations of this element were noted in group I products (an average of $1602 \mu \mathrm{g} / \mathrm{kg}$ ), the lowest in conventional hams $(1407 \mu \mathrm{g} / \mathrm{kg})$.

According to Ciborowska and Rudnicka [37], raw pork ham contains $9 \mathrm{mg} / \mathrm{kg}$ of iron, $18.8 \mathrm{mg} / \mathrm{kg}$ of zinc, $210 \mathrm{mg} / \mathrm{kg}$ of magnesium, 2,890 mg/kg of potassium, $50 \mathrm{mg} / \mathrm{kg}$ of calcium, and $0.2 \mathrm{mg} / \mathrm{kg}$ of copper. Wagner et al. [39] obtained the following results for the pressed hams: $123 \mathrm{mg} / \mathrm{kg}$ of magnesium, $9.5 \mathrm{mg} / \mathrm{kg}$ of zinc, and $6.9 \mathrm{mg} / \mathrm{kg}$ of iron. Smoked ham analyzed by Kunachowicz et al. [32] contained $9 \mathrm{mg} / \mathrm{kg}$ of iron, $17.9 \mathrm{mg} / \mathrm{kg}$ of zinc, $200 \mathrm{mg} / \mathrm{kg}$ of magnesium, $3660 \mathrm{mg} / \mathrm{kg}$ of potassium, $50 \mathrm{mg} / \mathrm{kg}$ of calcium, and $0.2 \mathrm{mg} / \mathrm{kg}$ of copper.

3.2. Potential Chemical Hazards. With the increase of consumers' awareness of the impact of nutrition on health, more interest in food additives is also seen. Some of the additives, despite the fact they are approved to be used in foods, are often considered by consumers as potentially harmful or possibly having irritant effects. In the list of substances authorized for use in the production of meat products, a number of allergens can be found. Therefore, consumers generally expect their food to have a limited amount of these additives [36].

Food products can also contain heavy metals such as cadmium, lead, arsenic, or mercury. They enter the foods mostly as a result of environmental contamination. These compounds accumulate in the body, and the symptoms of disease appear, even after many years. They are especially dangerous for children and infants. Cadmium and arsenic are carcinogenic. Cadmium has detrimental effects on the lungs and kidneys. Cadmium and lead can also cause a number of diseases such as anemia, diseases of the cardiovascular system, or blood pressure rise. Lead, cadmium, and mercury can cause diseases of the nervous system $[40,41]$.

The potential chemical food safety hazards of hams analyzed in this study are shown in Table 3. Profile chart (Figure 2) illustrates the differences between the three analyzed groups of hams regarding investigated chemical food safety hazards.

3.2.1. Phosphates. The phosphorus content in meat products depends on the amount of this element occurring naturally in meat and the quantity introduced in the production 


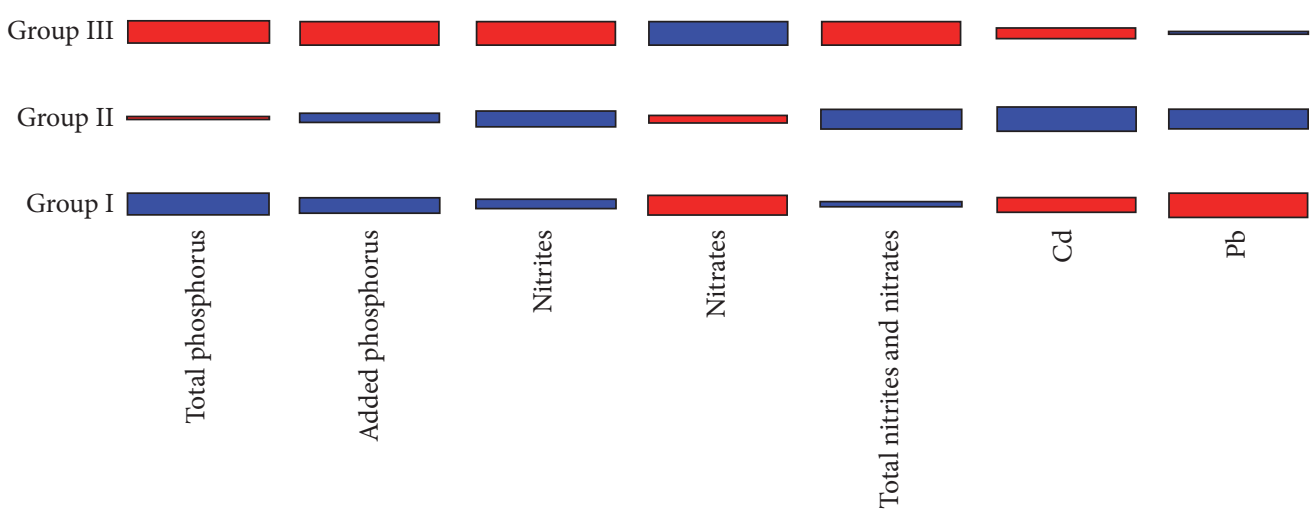

Figure 2: Profile chart - potential chemical food safety hazards.

process in the form of di-, tri-, and polyphosphates of sodium, potassium, and calcium [26]. The average content of phosphorus expressed as $\mathrm{P}_{2} \mathrm{O}_{5}$ in the analyzed hams was $0.55 \%$. Conventional hams contained more of this element $(0.64 \%)$ than unregistered traditional products $(0.53 \%)$ and products on the List of Traditional Products of the Polish Ministry of Agriculture and Rural Development (0.41\%). These differences were statistically significant.

In the research by Grześkowiak et al. [26], the analyzed hams contained on average approximately $0.42 \%$ phosphorus expressed as $\mathrm{P}_{2} \mathrm{O}_{5}$, which was similar to the value obtained for group I products in this study.

For consumers, however, information on the amount of added phosphorus in the production process is more important. According to the European Commission Regulation No. $1129 / 2011$, the amount of phosphorus expressed as $\mathrm{P}_{2} \mathrm{O}_{5}$ in meat products must not exceed $5000 \mathrm{mg} / \mathrm{kg}$ of the product, which is $0.5 \%$ of its weight. At the same time, the maximum daily dose of phosphates is $70 \mathrm{mg} / \mathrm{kg}$ of body weight.

All ham samples tested in the research met the legal requirements. Among the analyzed hams, the highest amount of phosphorus was added to the conventional products (on average $0.26 \% \mathrm{P}_{2} \mathrm{O}_{5}$ ). The addition of polyphosphates was, however, declared by all manufacturers. In unregistered traditional hams, on the other hand, a slight addition of phosphates (on average $0.04 \% \mathrm{P}_{2} \mathrm{O}_{5}$ ) was detected. In the case of traditional products, no polyphosphates were added. The difference in added phosphates content between all product groups was statistically significant.

In research by Kędzior and Machnik [42], an average amount of added phosphorus expressed as $\mathrm{P}_{2} \mathrm{O}_{5}$ was determined at the level of $0.1 \%$ for the ham samples tested. Szymański et al. [24] noticed a tendency to reduce the addition of phosphorus to smoked meat products. In the years 2002-2008, the average amount of phosphorus expressed as $\mathrm{P}_{2} \mathrm{O}_{5}$ in the analyzed products fell from $0.27 \%$ to $0.18 \%$. Nevertheless, they have studied the products aspiring to the title of the highest quality product in the meat industry. In our study, only conventional hams were characterized by comparable addition of phosphates (an average of $0.26 \%$ ). The trend noticed by Szymański et al. [24] is therefore maintained and now traditional hams are produced without even minimal addition of these compounds.
3.2.2. Nitrates and Nitrites. The presence of nitrites and nitrates in meat products is a result of their introduction in the production process at the stage of curing. The objective of this phase of production is to induce a specific and permanent pink color and provide the meat products with protection against the development of bacteria, as well as give them a desired flavor and delay the oxidation processes of fatty acids and cholesterol [5, 41, 43].

Considering the guidelines of the European Food Safety Authority, the acceptable limits of nitrites and nitrates used in meats to ensure microbiological safety of products were established. The requirements were set by Commission Regulation (EU) No. 1129/2011 of 11 November 2011 amending Annex II to Regulation (EC) No. 1333/2008 of the European Parliament and of the council by establishing a Union List of food additives, which came into force 1 June 2013. The addition of nitrites inhibits the production of toxins by nonproteolytic spores of Clostridium botulinum strains. The introduction of maximum permissible amounts of these compounds in the ready-to-eat processed meat products was, however, abandoned. The restrictions only limit the maximum permissible doses of the abovementioned substances that can be introduced into the product during technological process of production. The residues of nitrites and nitrates can in fact be differentiated, and the safety of the product is determined by the amount of these substances introduced during production. In addition, the nitrates can be used only when the products are not subjected to any heat treatment, and the maximum amount that can be used currently stands at $150 \mathrm{mg} / \mathrm{kg}$ of the product. Heating the nitrates leads to the formation of carcinogenic nitrosamines. Moreover, the vitamin $\mathrm{C}$ addition can be used to prevent the negative transitions of nitrites and nitrates. In the case of the traditional meat products indicated in Annex II of Regulation No. 1129/2011, the maximum amount of nitrates used in the listed products is $300 \mathrm{mg} / \mathrm{kg}$, whereas in the case of nitrites it was $180 \mathrm{mg} / \mathrm{kg}$. The maximum residues in the finished products are $250 \mathrm{mg} / \mathrm{kg}$ of nitrates and $175 \mathrm{mg} / \mathrm{kg}$ of nitrites, respectively $[44,45]$.

Nevertheless, it should be noted that nitrites and nitrates consumed by humans come mainly from vegetables (from approx. $80 \%$ [44] to $90 \%$ [46]) and water. Meat products are in the third place with less than 5\% of intake [47]. 
Researches show that small amounts of these compounds do not carry any risk to human health. What is more, they play an important role in regulating blood pressure, in preventing memory loss, and in the acceleration of wound healing. The human body itself produces nitrites and nitrates from arginine. Nonetheless, a dose of 3-5 grams of these compounds may pose a serious risk to people's lives. This is due to a higher affinity for oxygen than hemoglobin, which may lead to hypoxia. Moreover, nitrites with secondary amines may form carcinogenic nitrosamines in the stomach $[44,46,48]$.

According to Lücke [49], there is no good alternative for nitrites and nitrates. The use of vegetables rich in these compounds can lead to an overdose [41].

The precise estimation of addition of nitrites and nitrates used in the meat products' manufacturing process according to the assessment of residues in the final product seems impossible. This is due to the multidirectional conversions of those compounds during the technological processes. In particular, nitrites may be oxidized to nitrates in a low acidity environment [50]. Referring the total amounts of nitrites and nitrates for the analyzed products to the requirements of Regulation No. 1129/2011, it can, however, be stated with high probability that none of the tested meat products exceeded the allowed limits. The ham samples tested contained on average $20.7 \mathrm{mg} / \mathrm{kg}$ of nitrites and $16.2 \mathrm{mg} / \mathrm{kg}$ of nitrates.

The highest values of nitrates and nitrites were determined for conventional products. Hams belonging to this group contained on average $33.2 \mathrm{mg} / \mathrm{kg}$ of nitrites and $13.3 \mathrm{mg} / \mathrm{kg}$ of nitrates, and $46.5 \mathrm{mg} / \mathrm{kg}$ in total. The lower total content of nitrates characterized traditional hams registered on the list of Polish Ministry of Agriculture and Rural Development, $33.2 \mathrm{mg} / \mathrm{kg}$. These products contained more nitrates (average of $19.8 \mathrm{mg} / \mathrm{kg}$ ) than conventional products, but less nitrites, an average of $13.3 \mathrm{mg} / \mathrm{kg}$. The lowest contents of nitrogen compounds were determined in unregistered traditional hams (an average of $26.7 \mathrm{mg} / \mathrm{kg}$ of total nitrates, $9.02 \mathrm{mg} / \mathrm{kg}$ of nitrites, and $17.7 \mathrm{mg} / \mathrm{kg}$ of nitrates). Due to high standard deviations, statistically significant differences were found only between the contents of nitrites in conventional product and the other two groups of meat products.

In the research by Kędzior and Machnik [42], the average total content of nitrites and nitrates in pork hams was significantly higher than that obtained in this study, $82.4 \mathrm{mg} / \mathrm{kg}$.

3.2.3. Cadmium and Lead. In recent years, the level of lead content in food has gradually decreased in connection with the efforts to reduce lead emissions to the environment. Nevertheless, lead at low concentrations is still present in most foodstuffs. The highest level of this element can be found in meat offals and shellfish. The presence of lead in food products is the effect of inappropriate processing (pollution) or the production of food in contaminated areas $[15,41]$.

Cadmium occurs naturally in the environment. It is the component of the earth's crust and it accumulates in the soil. The major sources of cadmium are fruits and vegetables to which this element is transferred from the soil. It accumulates in kidney and liver. Half-life of cadmium accounts for 10 up to 30 years. Acceptable weekly intake of cadmium was lowered recently to $2.5 \mathrm{mg} / \mathrm{kg}$ body weight. For lead, the value is $25 \mathrm{mg} / \mathrm{kg}$ body weight $[41,51]$.

According to the Commission Regulation (EC) No. 1881/2006 of 19 December 2006 setting maximum levels for certain contaminants in foodstuffs, the lead content in the meat must not exceed the limit of $0.1 \mathrm{mg} / \mathrm{kg}$, whereas cadmium must not exceed $0.05 \mathrm{mg} / \mathrm{kg}$. The values obtained in the present study did not exceed the ones mentioned above.

The average content of lead $(\mathrm{Pb})$ in the ham samples tested accounted for $0.0299 \mathrm{mg} / \mathrm{kg}$. The highest content of this element characterized the hams from the List of Traditional Products of the Polish Ministry of Agriculture and Rural Development (approximately $0.049 \mathrm{mg} / \mathrm{kg}$ ). The differences, though, were not statistically significant.

The average concentration of cadmium (Cd) in the hams tested was $0.00392 \mathrm{mg} / \mathrm{kg}$. The statistical analysis showed no significant differences between the analyzed groups of products.

Wagner et al. [39] obtained results similar to or exceeding the allowed limit of the content of heavy metals in food products. The concentration of cadmium and lead in pressed hams accounted for $0.02 \mathrm{mg} / \mathrm{kg}$ and $0.39 \mathrm{mg} / \mathrm{kg}$, respectively. Traditional hams tested by Alturiqi and Albedair [52] exceeded acceptable limits for the content of cadmium and lead.

\section{Conclusions}

Traditional hams examined in the present study were characterized by the highest nutritional value among all of the groups of products analyzed. They had the lowest water and highest protein content. In addition, traditional hams were distinguished by the low concentration of sodium chloride and no addition of phosphates, which resulted in a low content of total ash. The residues of nitrites and nitrates indicate their moderate use in manufacturing processes. Moreover, traditional products had the most favorable water/protein ratio among the studied groups of products. They were also characterized by the highest content of iron, zinc, and copper.

Conventional hams, on the other hand, exhibited the highest content of water, sodium chloride, phosphates, and total ash and the lowest concentration of protein. Hence, they had the least favorable water/protein ratio among the analyzed groups of products. They contained less nitrates but more nitrites than the traditional products.

The unregistered traditional products were characterized by parameter values either on intermediate level or on the level similar to the ones exhibited by products registered as traditional. In their production, comparable amounts of nitrites and nitrates to those used for curing hams registered on the List of Traditional Products of the Polish Ministry of Agriculture and Rural Development were added. The unregistered traditional hams were distinguished by the highest content of magnesium and potassium.

\section{Additional Points}

Practical Applications. The results presented in the article contribute to the debate on the differences between traditional 
and conventional food products. The literature highlights a wide variation between the nutritional values of meat products manufactured with the use of industrial methods and those that have been produced without additives. However, there is a lack of information on the quality and composition of traditional smoked meats in comparison to their conventional equivalents. Therefore, the data presented in the manuscript can be used both by consumers to learn about the differences between these two groups of products and by scientists worldwide for comparison with their research results.

\section{Conflicts of Interest}

The authors declare that there are no conflicts of interest regarding the publication of this paper.

\section{Acknowledgments}

This research was subsidized by the Ministry of Science and Higher Education, grant for the maintenance of the research potential, awarded to the Faculty of Commodity Science of the Cracow University of Economics.

\section{References}

[1] F. K. Lücke and I. Vogeley, “Traditional 'air-dried' fermented sausages from Central Germany," Food Microbiology, vol. 29, no. 2, pp. 242-246, 2012.

[2] N. Cayot, "Sensory quality of traditional foods," Food Chemistry, vol. 101, no. 1, pp. 154-162, 2006.

[3] R. Talon, I. Lebert, A. Lebert et al., "Traditional dry fermented sausages produced in small-scale processing units in Mediterranean countries and Slovakia. 1: Microbial ecosystems of processing environments," Meat Science, vol. 77, no. 4, pp. 570-579, 2007.

[4] T. Krzywiński and G. Tokarczyk, "Tradycyjne wyroby mięsne wysokiej jakości," Wielkanocny stót. Polaków, Przemyst Spożywczy, vol. 3, no. 66, pp. 2-6, 2012.

[5] M. Florek, P. Domaradzki, P. Skałecki, and A. Wrona, "Jakosc krajowych i importowanych wedlin klasy premium," Gospodarka Miesna, vol. 6, pp. 26-35, 2013.

[6] PN-A-04018:1975/Az3:2002, Agricultural food products. Nitrogen contents determination with Kjeldahl's method and recalculation into protein.

[7] PN-ISO 1442:2000, Meat and meat products. Water contents determination.

[8] PN-ISO 1444:2000, Meat and meat products. Free fat contents determination.

[9] PN-73/A-82112:1973, Meat and meat products. Determination of sodium chloride content.

[10] PN-ISO 936:2000, Meat and meat products. Determination of total ash content.

[11] PN-EN 12014-3:2006/Ap1:2008, Foodstuffs. Determination of nitrate and/or nitrite content. Part 3: Spectrometric determination of nitrate and nitrite content of meat products after enzymatic reduction of nitrate to nitrite.

[12] PN-A-82060:1999, Meat and meat products. Phosphorus contents determination.
[13] K. Krajewski, A. Tul-Krzyszczuk, P. Kondraciuk, and M. Świątkowska, "Doświadczenia i znaczenie produktów tradycyjnych w promocji regionów," in $Z$ Rozwój turystyczny regionów, a tradycyjna żywność, Z. Dolatowski and D. KołożynKrajewska, Eds., pp. 102-117, PTTŻ, WSHiT, Częstochowa, Poland, 2009.

[14] REGULATION (EU) No 1151/2012 of the European Parliament and of the Council of 21 November 2012 on quality schemes for agricultural products and foodstuffs, Official Journal of the European Union.

[15] T. S. Aranha, A. Oliveira, H. M. Queiroz, and S. Cadore, "A fast alkaline treatment for cadmium determination in meat samples," Food Control, vol. 59, pp. 447-453, 2016.

[16] S. De Smet and E. Vossen, "Meat: the balance between nutrition and health: a review," Meat Science, vol. 120, pp. 145-156, 2016.

[17] K. Krysztofiak and A. Bilska, "Wędliny," in Towaroznawstwo żywności pochodzenia zwierzęcego, E. Flaczyk, D. Górecka, and J. Korczak, Eds., pp. 243-266, Wydawnictwo Uniwersytetu Przyrodniczego w Poznaniu, Poznań, Poland, 2011.

[18] A. J. Gaitán-Jurado, V. Ortiz-Somovilla, F. España-España, J. Pérez-Aparicio, and E. J. De Pedro-Sanz, "Quantitative analysis of pork dry-cured sausages to quality control by NIR spectroscopy," Meat Science, vol. 78, no. 4, pp. 391-399, 2008.

[19] F. Toldrá, Dry-Cured Meat Products, Willey-Blackwell, Ames, Iowa, USA, 2002.

[20] M. Lucarini, G. Saccani, L. D’Evoli et al., "Micronutrients in Italian ham: A survey of traditional products," Food Chemistry, vol. 140, no. 4, pp. 837-842, 2013.

[21] N. Marušić, S. Vidaček, T. Janči, T. Petrak, and H. Medić, "Determination of volatile compounds and quality parameters of traditional Istrian dry-cured ham," Meat Science, vol. 96, no. 4, pp. 1409-1416, 2014.

[22] T. Szmańko, M. Oziembłowski, E. Dworacka, and D. Dobrowolska, "Sensory quality and selected physicochemical properties of processed meat products produced in different plants," Acta Scientiarum Polonorum, Technologia Alimentaria, vol. 5, no. 2, pp. 93-105, 2006.

[23] M. Florek, P. Skałecki, A. Litwinczuk, K. Respondowska, and A. Litwińczuk, "Ocena towaroznawcza szynek wedzonych dostepnych w sieci detalicznej miasta Lublina," Polish Journal of Commodity Science, vol. 2, no. 35, pp. 113-122, 2013.

[24] P. Szymański, M. Wawrzyniewicz, P. Moch, A. Plaskota, and J. Kern-Jędrychowski, "Tendencje zmian jakościowych wybranych kiełbas suszonych i wędzonek obserwowane w latach 2000-2008 na podstawie wyników badań chemicznych produktów zgłaszanych na konkurs, Produkty najwyższej jakości w przemyśle mięsnymkonkurs Produkty najwyzszej jakosci w przemysle miesnym," Roczniki Instytutu Przemysłu Mięsnego i Tłuszczowego, vol. 2, no. 47, pp. 116-133, 2009.

[25] B. Garbowska, M. Radzymińska, and D. Jakubowska, "Influence of the origin on selected determinants of the quality of pork meat products," Czech Journal of Food Sciences, vol. 31, no. 6, pp. 547-552, 2013.

[26] E. Grześkowiak, M. Fabian, and D. Lisiak, "Ocena zawartości fosforu oraz jakości mięsa i przetworów mięsnych dostępnych na rynku krajowym," Żywność Nauka Technologia Jakość, vol. 2, no. 75, pp. 160-179, 2011.

[27] F. Jiménez-Colmenero, J. Ventanas, and F. Toldrá, "El jamón curado en unanutrición saludable," in Proceedings of the 5th World Congress of Dry-Cured Ham, Aracena, Spain, May 2009.

[28] L. D’Evoli, M. Lucarini, S. Nicoli, A. Aguzzi, P. Gabrielli, and G. Lombardi-Boccia, "Nutritional profile of traditional Italian 
hams," in Proceeding of the 5th World Congress of Dry-Cured Ham, Aracena, Spain, May 2009.

[29] M. Fernández, J. A. Ordóñez, I. Cambero, C. Santos, C. Pin, and L. de la Hoz, "Fatty acid compositions of selected varieties of Spanish dry ham related to their nutritional implications," Food Chemistry, vol. 101, no. 1, pp. 107-112, 2006.

[30] F. Jiménez-Colmenero, J. Ventanas, and F. Toldrá, "Nutritional composition of dry-cured ham and its role in a healthy diet," Meat Science, vol. 84, no. 4, pp. 585-593, 2010.

[31] N. Marušić, M. Petroví, S. Vidaček, T. Petrak, and H. Medić, "Characterization of traditional Istrian dry-cured ham by means of physical and chemical analyses and volatile compounds," Meat Science, vol. 88, no. 4, pp. 786-790, 2011.

[32] H. Kunachowicz, I. Nadolna, B. Przygoda, and K. Iwanow, Tabele składu $i$ wartości odżywczej żywności, Wydawnictwo Lekarskie PZWL, Warszawa, Poland, 2005.

[33] M. Flores, A. Olivares, and S. Corral, "Healthy trends affect the quality of traditional meat products in Mediterranean area," Acta Agriculturae Slovenica, supplement 4, pp. 183-188, 2013.

[34] H. A. S. Beernaert, F. M. C. Van der Mijnsbrugge, and J.-M. C. J. G. De Martelaere, "Determination of salt in potato chips," Zeitschrift für Lebensmittel-Untersuchung und -Forschung, vol. 178, no. 1, pp. 27-30, 1984.

[35] S. N. Papadima and J. G. Bloukas, "Effect of fat level and storage conditions on quality characteristics of traditional Greek sausages," Meat Science, vol. 51, no. 2, pp. 103-113, 1999.

[36] N. Z. Ballin, "Authentication of meat and meat products," Meat Science, vol. 86, no. 3, pp. 577-587, 2010.

[37] H. Ciborowska and A. Rudnicka, Dietetyka. Żywienie zdrowego i chorego człowieka, Wydawnictwo Lekarskie PZWL, Warszawa, Poland, 2010.

[38] M. S. Islam, M. K. Ahmed, M. Habibullah-Al-Mamun, and M. Raknuzzaman, "The concentration, source and potential human health risk of heavy metals in the commonly consumed foods in Bangladesh," Ecotoxicology and Environmental Safety, vol. 122, pp. 462-469, 2015.

[39] J. Wagner, R. Glaza, W. Lewandowski et al., “Zawartość mikroi makroelementów w mięsie i niektórych wędlinach,” Przemyst Spożywczy, vol. 12, pp. 49-51, 2000.

[40] L. A. Nasser, "Molecular identification of isolated fungi, microbial and heavy metal contamination of canned meat products sold in Riyadh, Saudi Arabia," Saudi Journal of Biological Sciences, vol. 22, no. 5, pp. 513-520, 2015.

[41] S. Andrée, W. Jira, K.-H. Schwind, H. Wagner, and F. Schwägele, "Chemical safety of meat and meat products," Meat Science, vol. 86, no. 1, pp. 38-48, 2010.

[42] W. Kędzior and D. Machnik, "Badanie i ocena zawartości azotynów i azotanów oraz fosforu w wędlinach," Cracow Review of Economics and Management, vol. 583, pp. 35-41, 2002.

[43] J. Kabisch, R. Scheuer, W. Roedel, and M. Gareis, "Influence on the microbial effect of sodium nitrite in raw fermented sausage," Mitteilungsblatt der Fleischforschung Kulmbach, vol. 47, pp. 99105, 2008.

[44] J. J. Sindelar, "What's the Deal with Nitrates and Nitrities Used in Meat Products?" http://fyi.uwex.edu/meats/files/2012/02/Nitrate-and-nitrite-in-cured-meat_10-18-2012.pdf.

[45] P. Szymański, "Unijny wykaz dodatków do żywności - nowe przepisy dla branży mięsnej," Gospodarka Mięsna, vol. 7, pp. 2427, 2013.

[46] Anonymous, "Nitrites - nitrates," Mięso i Wędliny, vol. 52, article 42, 2008.
[47] D. L. Archer, "Evidence that ingested nitrate and nitrite are beneficial to health," Journal of Food Protection, vol. 65, no. 5, pp. 872-875, 2002.

[48] K.-O. Honikel, "The use and control of nitrate and nitrite for the processing of meat products," Meat Science, vol. 78, no. 1-2, pp. 68-76, 2008.

[49] F. K. Lücke, "Use of nitrite and nitrate in the processing of meat from organic production - Benefits and risks," Fleischwirtschaft, vol. 83, no. 11, pp. 138-142, 2003.

[50] COMMISSION REGULATION (EU) No 1129/2011 of 11 November 2011 amending Annex II to Regulation (EC) No 1333/2008 of the European Parliament and of the Council by establishing a Union list of food additives, Official Journal of the European Union.

[51] EFSA (European Food Safety Authority), "Cadmium dietary exposure in the European population," EFSA Journal, vol. 10, no. 1, pp. 1-37, 2012.

[52] A. S. Alturiqi and L. A. Albedair, "Evaluation of some heavy metals in certain fish, meat and meat products in Saudi Arabian markets," The Egyptian Journal of Aquatic Research, vol. 38, no. 1, pp. 45-49, 2012. 

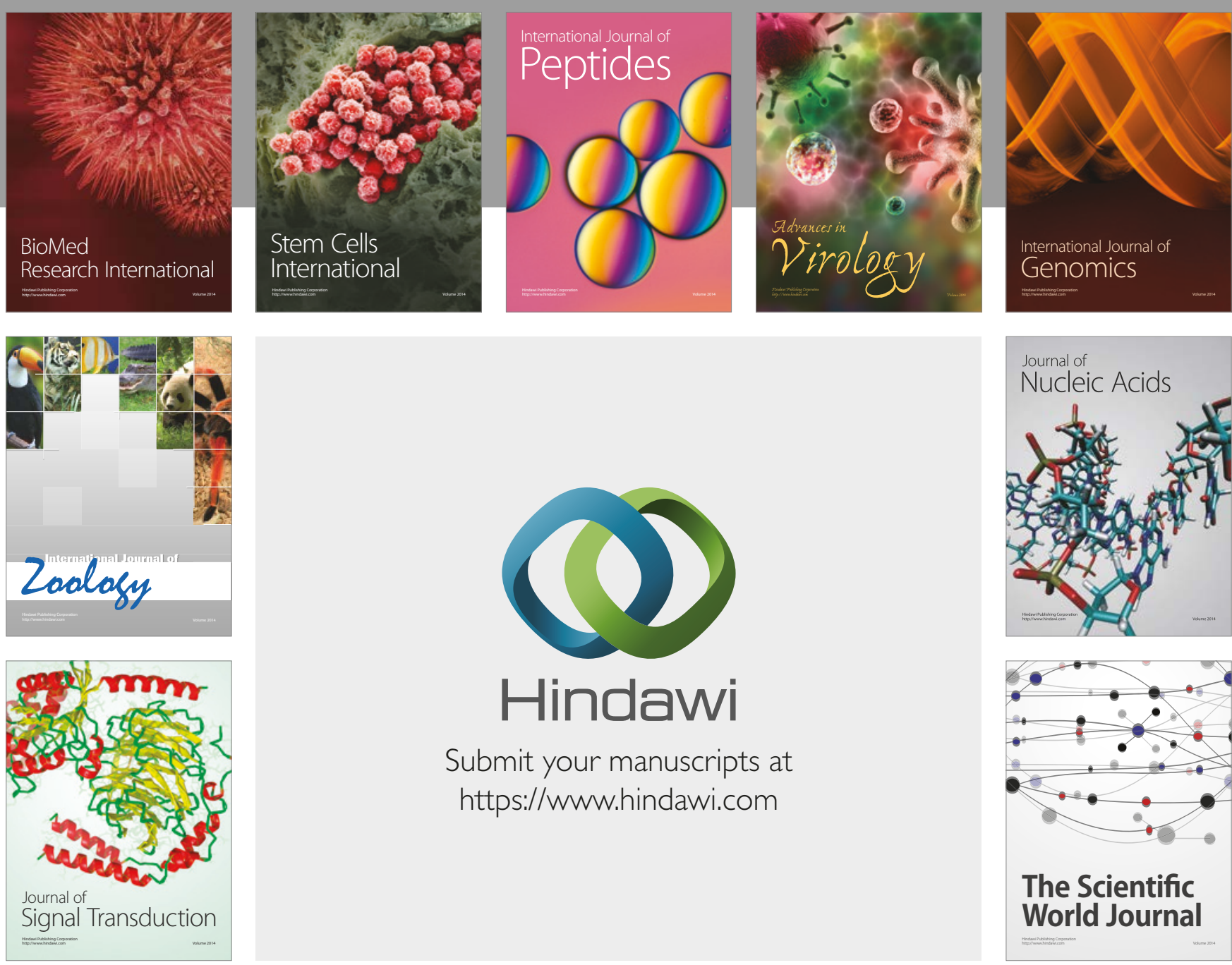

Submit your manuscripts at

https://www.hindawi.com
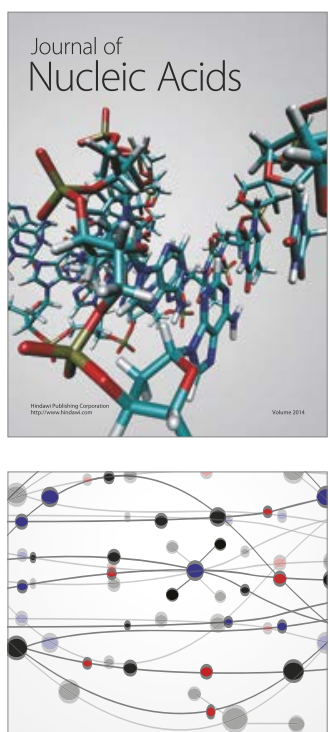

The Scientific World Journal

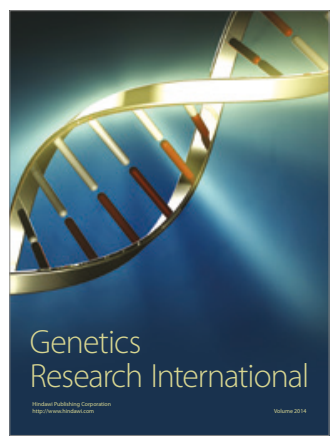

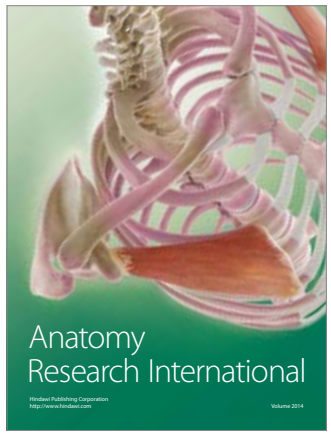

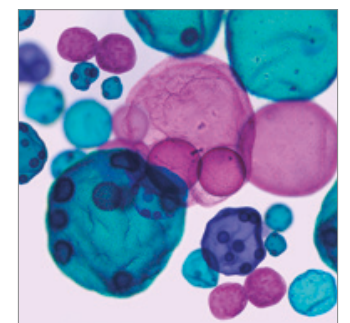

International Journal of Microbiology
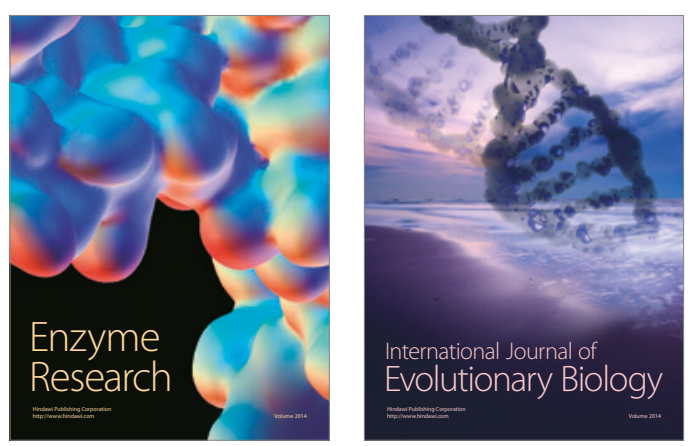
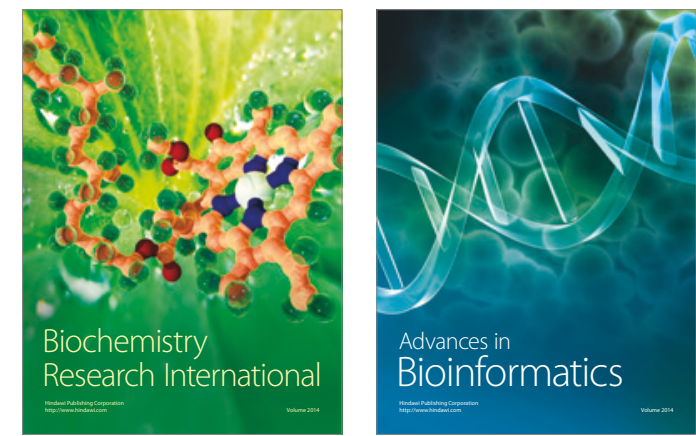

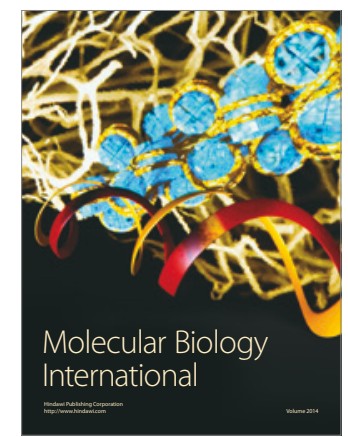

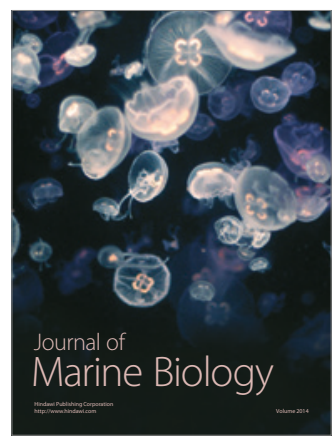

